\title{
Association Between Central Corneal Thickness and Growth Parameters Following Preterm Birth
}

\section{Preterm Doğum Sonrası Merkezi Kornea Kalınlık ve Büyüme Parametreleri Arasındaki İlişki}

\author{
Gokhan CELIK, Murat GUNAY, Osman KIZILAY, Abdulhamit TUTEN ${ }^{3}$ \\ 1 Zeynep Kamil Maternity and Children's Diseases Training and Research Hospital, Department of Ophthalmology, Istanbul, Turkey \\ 2 Karadeniz Technical University, School of Medicine, Department of Ophthalmology, Trabzon, Turkey \\ 3 Hitit University, Erol Olcok Training and Research Hospital, Department of Neonatology, Corum, Turkey
}

Yazışma Adresi

Correspondence Address

\section{Gokhan CELIK}

Zeynep Kamil Maternity and Children's Diseases Training and Research Hospital, Department of Ophthalmology, Istanbul, Turkey gcelik279@hotmail.com

Geliş tarihi / Received : Aralık 28, 2020 Kabul tarihi / Accepted : Şubat 09, 2021 Elektronik yayın tarihi : Ocak 01, 2022 Online published

Bu makalede yapılacak atıf:

Cite this article as:

Celik G, Gunay M,

Kizilay O, Tuten A.

Association Between Central

Corneal Thickness and

Growth Parameters Following

Preterm Birth.

Akd Med J 2022; 8(1):28-32

Gökhan Çelik

ORCID 0000-0003-2111-0420

Murat Gunay

ORCID 0000-0002-8874-1473

Osman Kizılay

ORCID 0000-0002-0948-3550

Abdulhamit Tüten

ORCID 0000-0002-0024-8458

\section{ABSTRACT \\ Objective:}

To investigate central corneal thickness in prematurely born children and to evaluate the association between central corneal thickness and growth pattern during 3 months following preterm birth.

\section{Methods:}

In this prospective study, central corneal thickness, head circumference, body length and body weight measurements were performed in 32 infants at monthly intervals during the first 3 months following preterm birth. Central corneal thickness measurements were performed by using an ultrasonic pachymetry. Initial central corneal thickness measurements were performed $24-48$ hours after delivery. The head circumference, body length and body weight measurements were performed within 24 hours following birth by a neonatologist. All measurements were carried out at 1st month, 2nd month and 3rd month in the same manner.

\section{Results:}

There were 18 female $(56.2 \%)$ and 14 male (43.8\%) infants. The mean gestational age and body weight at birth were 27.8 weeks and $1042 \pm 309.9 \mathrm{~g}$, respectively. The mean head circumference and body length at birth were $26.2 \mathrm{~cm}$ and $36.3 \mathrm{~cm}$, respectively. Mean central corneal thickness at birth was $666.03 \pm 92.6 \mu \mathrm{m}$. Central corneal thickness significantly decreased during the study period $(\mathrm{p}<0.001)$. Head circumference, body length and body weight showed significant increases following birth $(p<0.001$ for each). There was a significant negative correlation of central corneal thickness change with the body length change between 1st month and 2nd month $(\mathrm{p}<0.05)$.

\section{Conclusion:}

In this study, decrease of corneal thickness in prematurely born infants was found to be inversely correlated to body length alterations in early months of life.

Key Words: Body length, Body weight, Central corneal thickness, Head circumference measurement, Premature

ÖZ

\section{Giriş/Amaç:}

Prematüre doğan çocuklarda santral kornea kalınlığını ölçmek ve preterm doğumu takip eden 3 ay boyunca merkezi kornea kalınlığı ile büyüme değerleri arasındaki ilişkiyi karşılaştırmak. 
Gereç ve Yöntemler: $\mathrm{Bu}$ ileriye dönük çalışmada preterm doğumu takiben 32 çocukta 3 ay boyunca aylık aralıklarla santral kornea kalınlığı, baş çevresi, vücut uzunluğu ve vücut ağırlığı ölçümleri yapıldı. Santral kornea kalınlığı ölçümleri ultrasonik pakimetre cihazı kullanılarak yapıldı. İlk santral kornea kalınlığı ölçümleri doğumdan sonraki 24 - 48 saat içerisinde yapıldı. Baş çevresi, vücut uzunluğu ve vücut ağırlığı ölçümleri yenidoğan uzmanı tarafından doğumdan sonraki 24 saat içinde yapıldı. Tüm ölçümler 1. ayda, 2. ayda ve 3. ayda aynı şekilde gerçekleştirildi.

\section{Bulgular:}

Çalışmada 18 kız $(\% 56,2)$ ve 14 erkek $(\% 43,8)$ bebek vardı. Ortalama doğum haftası ve ağırlığ 1 sirasiyla 27,8 hafta ve $1042 \pm 309,9$ g idi. Ortalama baş çevresi ve vücut uzunluğu sirasıyla $26,2 \mathrm{~cm}$ ve $36,3 \mathrm{~cm}$ idi. Doğumda ortalama merkezi kornea kalınlığı 666,03 $\pm 92,6 \mu \mathrm{m}$ idi. Çalışma sırasında merkezi kornea kalınlığ önemli ölçüde azaldı $(\mathrm{p}<0.001)$. Baş çevresi, vücut uzunluğu ve vücut ağırlı̆̆ı doğumdan sonra önemli artışlar gösterdi ( $\mathrm{p}<0.001$ hepsi için). Birinci ay ile 2 . ay arasında santral kornea kalınlığındaki değişim ile vücut uzunluğundaki değişim arasında anlamlı bir negatif korelasyon vard1.

\section{Sonuç:}

$\mathrm{Bu}$ çalıșmada, prematüre bebeklerde kornea kalınlığındaki azalmanın, yaşamın erken evrelerinde vücut uzunluğundaki değişikliklerle ters ilişkili olduğu bulunmuştur.

Anahtar Sözcükler: Vücut uzunluğu, Vücut ağırlığı, Merkezi kornea kalınlığı, Baş çevresi ölçümü, Prematüre

\section{INTRODUGTION}

There are several studies in the literature that issued central corneal thickness (CCT) in premature infants. Earlier studies have found CCT to be thicker in premature children which shows significant decrease towards term $(1,2)$. Moreover, CCT was found to be slightly thicker in premature children compared with term born children (3).

The CCT measurement plays an important role especially in diagnosis and treatment of congenital glaucoma patients. Hence appropriate assessment of the CCT is mandatory in preterm infants (4). There are several signs of maturity in neonates. Head circumference (HC), body length (BL) and body weight $(\mathrm{BW})$ have been well-accepted quantitative growth references to indicate neonatal maturity. These parameters have been found to be reliable while investigating the maturity level in children (5).

Previously, Rushood et al. investigated the relationship between CCT values and growth reference parameters following birth. The study involved measurement of CCT in 100 Saudi full-term born infants and found no correlation between CCT and gestational age (GA), HC, BL and BW. However, all measurements were performed at a single time point (during the first 6 days of birth) (6).

Our primary aim in the present study was to assess CCT and growth reference parameters of premature infants during their first 3 months and to investigate the association between changes in CCT and changes in $\mathrm{HC}, \mathrm{BL}$ and $\mathrm{BW}$.

\section{METHODS}

Upon approval of Institutional Review Board (19.09.2014/163), this study was carried out in Zeynep Kamil Maternity and Children's Diseases Training and Research Hospital in full accord with the principles laid out in the Declaration of Helsinki. Informed consent was obtained from the parents of the infants prior to inclusion in the study. The $\mathrm{CCT}, \mathrm{HC}, \mathrm{BL}$ and $\mathrm{BW}$ measurements were performed at monthly intervals during the first 3 months following preterm birth. The subjects were from the nonatal intensive care unit of the same institute. Clinically stable infants born at $\leq 32$ weeks of gestation period were included in the study. Infants with any congenital ocular and/or systemic abnormality were excluded.

The CCT measurements were performed under topical anesthesia (with proparacaine hydrochloride $0.5 \%$ eye drop by using a ultrasonic pachymetry device (AccuPach VI Pachymeter, Accutome, Malvern, PA, USA). During CCT measurements, an experienced nurse fixed the infants at supine position and infants were monitored by a neonatologist.

Initial CCT measurements were performed within 24 to 48 hours after delivery. Ten consecutive measurements were obtained and the average reading was noted. Isopropyl alcohol swab was used for disinfection of the ultrasonic probe tip before application to each eye. Same procedures were applied at all-time points including first, second and third months.

The HC, BL and BW measurements were performed by a neonatologist within 24 hours after birth as part of the standart care.

Calibrated digital scales were utilized during BW measurements at birth. Infant length board was used to measure BL which was recorded to the nearest $0.1 \mathrm{~cm}$. Measurement of $\mathrm{HC}$ was performed via flexible nonstretch tape measure to the nearest $0.1 \mathrm{~cm}$. Following discharge, infants were reviewed in neonatal follow-up clinic and anthropometrics were recorded at 1st, 2nd and 3rd months of life.

\section{Statistical Analysis}

MedCalc Statistical Software version 12.7.7 (MedCalc Software bvba, Ostend, Belgium; http://www.medcalc.org; 2013) program was used for the statistical analysis. Descriptive statistics were used for the continuous variables (mean, standard deviation, and minimum, median, maximum). Student $t$ test and Mann Whitney U test were used to compare variables according to the distribution of the data. Pearson correlation analysis and Spearman's rho correlation analysis were used according to the distribution of the two continuous variables. Changes between the measurements in each visit were examined with Friedman and Repeated Measures ANOVA tests along with Post-Hoc analyses (Wilcoxon Signed Rank and Bonferroni tests) depending on the distribution. Significance level was $\mathrm{p}<0.05$. 
Association Between Central Corneal Thickness and Growth Parameters Following Preterm Birth

\section{RESULTS}

A total of 32 premature infants were included in this study. There were 18 female (56.2\%) and 14 male (43.8\%) infants. The mean GA and BW at birth were 27.8 weeks ( 23 weeks to 32 weeks) and $1042 \pm 309.9 \mathrm{~g}$ (610 g to $1820 \mathrm{~g})$, respectively. The mean $\mathrm{HC}$ and BL at birth were $26.2 \mathrm{~cm}(22 \mathrm{~cm}$ to $33 \mathrm{~cm})$ and $36.3 \mathrm{~cm}$ ( $30 \mathrm{~cm}$ to $48 \mathrm{~cm})$, respectively. Several systemic risk factors of the infants are summarized in Table I.

Table I. Systemic risk factors of the infants

\begin{tabular}{lll}
\hline & N & $\%$ \\
\hline C/S delivery & 25 & 78.1 \\
Twin birth & 6 & 18.8 \\
IUGR & 10 & 31.3 \\
PROM & 12 & 37.5 \\
Oligohydramnios & 2 & 6.3 \\
Preeclampsia & 10 & 31.3 \\
Antenatal steroid & 24 & 75 \\
RDS & 30 & 93.8 \\
IVH & 11 & 34.4 \\
NEC & 11 & 34.4 \\
PDA & 7 & 21.9 \\
BPD & 19 & 59.4 \\
\hline
\end{tabular}

IUGR: Intrauterine growth restriction, PROM: Premature rupture of membranes, RDS: Respiratory distress syndrome, IVH: Intraventricular hemorrhage, NEC: Necrotizind enterocolitis, PDA: Patent ductus arteriosus, BPD: Bronchopulmonary dysplasia

There were no significant differences of the CCT values between right and left eyes of the infants at each measurement points $(\mathrm{p}>0.05)$ (Table II).
Table II. CCT measurements of right and left eyes in the study

\begin{tabular}{llll}
\hline & $\begin{array}{l}\text { Right eye CCT }(\mu \mathrm{m}) \\
\text { Mean } \pm \text { SD } \\
\text { (Min.-Max.) }\end{array}$ & $\begin{array}{l}\text { Left eye CCT }(\mu \mathrm{m}) \\
\text { Mean } \pm \text { SD } \\
\text { (Min.-Max. })\end{array}$ & $\mathrm{p}$ \\
\hline Birth & $\begin{array}{l}666.03 \pm 92.6 \\
(432 \text { to } 913)\end{array}$ & $\begin{array}{l}674.53 \pm 92.6 \\
(458 \text { to } 887)\end{array}$ & $0.72^{*}$ \\
1. month & $\begin{array}{l}616.1 \pm 66.7 \\
(441 \text { to } 716)\end{array}$ & $\begin{array}{l}623.8 \pm 72.1 \\
(431 \text { to } 715)\end{array}$ & $0.51^{* *}$ \\
& & & \\
2. month & $575.59 \pm 63.4$ & $577.4 \pm 63.1$ & $0.91^{*}$ \\
& $(462$ to 696$)$ & $(462$ to 720$)$ & \\
3. month & $546.76 \pm 49.4$ & $546.3 \pm 48$ & $0.97^{*}$ \\
& $(458$ to 887$)$ & $(454$ to 666$)$ & \\
\hline *Student $t$ test, ** & & &
\end{tabular}

*Student $t$ test, **Mann-Whitney U tes

CCT: central corneal thickness

Therefore, right eyes of the infants were included for statistical analysis in the study. The mean CCT was $666.03 \pm 92.2 \mu \mathrm{m}$ (432 $\mu \mathrm{m}$ to $913 \mu \mathrm{m})$ at birth, $616.1 \pm 66.7 \mu \mathrm{m}(441 \mu \mathrm{m}$ to 716 $\mu \mathrm{m})$ at $1 \mathrm{st}$ month, $575.59 \pm 63.4 \mu \mathrm{m}(462 \mu \mathrm{m}$ to $696 \mu \mathrm{m})$ at 2nd month and $546.76 \pm 49.4 \mu \mathrm{m}(458 \mu \mathrm{m}$ to $887 \mu \mathrm{m})$ at $3 \mathrm{rd}$ month. There was a significant decrease of CCT during first 3 months period following birth (Bonferroni correction for CCT, $\mathrm{p}<0.008)$. HC, BL and BW showed significant increase during the study period after birth (Bonferroni correction for $\mathrm{HC}$ and $\mathrm{BL}, \mathrm{p}<0.008$ and Wilcoxon Signed Rank for BW, $\mathrm{p}<0.008)$. Changes in CCT, HC, BL and BW are shown in Table III.

Table III. CCT, HC, BL and BW changes during the study

\begin{tabular}{|c|c|c|c|c|}
\hline & $\begin{array}{l}\text { CCT }(\mu \mathrm{m}) \\
\text { Mean } \pm \text { SD } \\
(\text { Min.-Max.) }\end{array}$ & $\begin{array}{l}\mathrm{HC}(\mathrm{cm}) \\
\text { Mean } \pm \text { SD } \\
\text { (Min.-Max.) }\end{array}$ & $\begin{array}{l}\text { BL }(\mathrm{cm}) \\
\text { Mean } \pm \text { SD } \\
\text { (Min.-Max.) }\end{array}$ & $\begin{array}{l}\text { BW (g) } \\
\text { Mean } \pm \text { SD } \\
\text { (Min.-Max.) }\end{array}$ \\
\hline Birth & $\begin{array}{l}666.03 \pm 92.2 \\
\text { (432 to } 913 \text { ) }\end{array}$ & $\begin{array}{l}26.2 \pm 2.6 \\
\text { (22 to } 33 \text { ) }\end{array}$ & $\begin{array}{l}36.3 \pm 4.1 \\
(30 \text { to } 48)\end{array}$ & $\begin{array}{l}1042 \pm 309.9 \\
(610 \text { to } 1820)\end{array}$ \\
\hline 1. month & $\begin{array}{l}616.1 \pm 66.7 \\
(441 \text { to } 716)\end{array}$ & $\begin{array}{l}29.1 \pm 2.7 \\
\text { (24 to } 35 \text { ) }\end{array}$ & $\begin{array}{l}39.3 \pm 3.6 \\
(33 \text { to } 47)\end{array}$ & $\begin{array}{l}1402 \pm 359.6 \\
(930 \text { to } 2260 \text { ) }\end{array}$ \\
\hline 2. month & $\begin{array}{l}575.59 \pm 63.4 \\
\text { (462 to } 696 \text { ) }\end{array}$ & $\begin{array}{l}32.7 \pm 2.8 \\
(26 \text { to } 40)\end{array}$ & $\begin{array}{l}43.9 \pm 3.6 \\
(39 \text { to } 52)\end{array}$ & $\begin{array}{l}2138.6 \pm 510.5 \\
(1400 \text { to } 3600)\end{array}$ \\
\hline 3. month & $\begin{array}{l}546.76 \pm 49.4 \\
\text { (458 to } 887 \text { ) }\end{array}$ & $\begin{array}{l}35.7 \pm 2.6 \\
(29 \text { to } 42)\end{array}$ & $\begin{array}{l}48.6 \pm 4.1 \\
(40 \text { to } 46)\end{array}$ & $\begin{array}{l}2972.2 \pm 660.2 \\
(1890 \text { to } 4650)\end{array}$ \\
\hline$p$ & $<0.001^{*}$ & $<0.001^{*}$ & $<0.001^{*}$ & $<0.001^{* *}$ \\
\hline
\end{tabular}

*Repeated Measures ANOVA, **Friedman test

CCT: central corneal thickness, HC: head circumference, BL: body length, BW: body weight

Table IV provides correlation analysis between the changes in CCT and changes in $\mathrm{HC}, \mathrm{BL}, \mathrm{BW}$ in the study. It was found that, there was a significant negative correlation of CCT change with the BL change between 1st month - 2nd month $(\mathrm{r}=-0.476, \mathrm{p}=0.009)$.

Table IV. Correlation analysis between changes in CCT and changes in $\mathrm{HC}, \mathrm{BL}$ and $\mathrm{BW}$ during the study

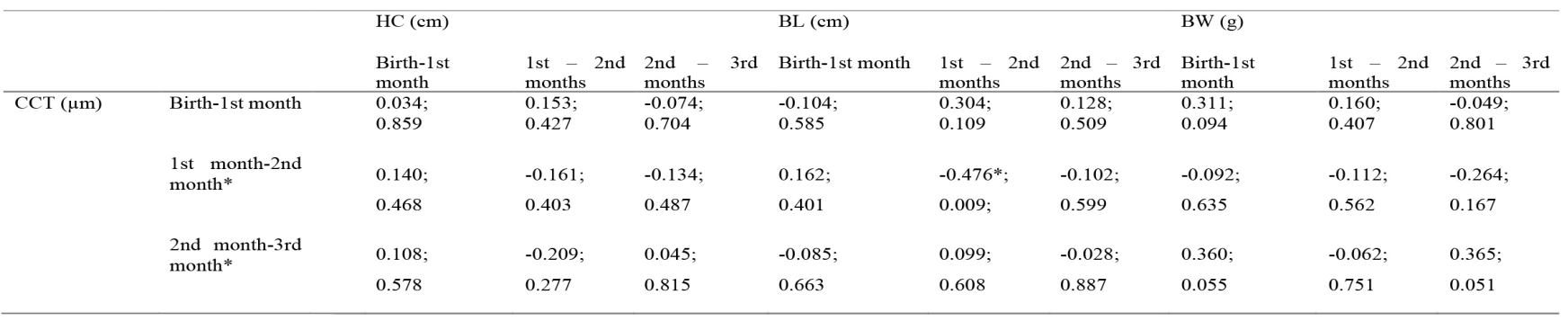

Pearson correlation analysis, $\mathrm{p}<0.05^{*} \mathrm{CCT}$ : central corneal thickness, $\mathrm{HC}$ : head circumference, BL: body length, BW: body weight *Results are expressed as $(\mathrm{r} ; \mathrm{p})$ 


\section{DISGUSSION}

CCT in premature and term infants were analysed in several studies (1-4,6-10). Table V summarizes some of these studies with qualitative CCT measurements. De Silva et al. (8) showed a decrease of CCT from $794 \mu \mathrm{m}$ to $559 \mu \mathrm{m}$ at 28 weeks to 42 weeks of post conceptual age. Erginturk Acar et al. (9) demonstrated a longitudinal decrease in CCT values in healthy premature infants between 32 and 40 weeks gestational age. Similar findings were observed regarding change of CCT in the present study.

A mean CCT of $666.03 \pm 92.2 \mu \mathrm{m}$ at birth and a mean CCT of $546.76 \pm 49.4 \mu \mathrm{m}$ after 3 months following delivery were found. This finding indicates a considerable CCT reduction towards term.

In a premature newborn, generally, a hazy cornea with reduced corneal transparency is observed. Dehydration of the cornea along with an increase in evaporation rate has been proposed to be the reason of a decrease in CCT following preterm birth (10). Animal studies have also shown that regulation of biomechanical components of the cornea such as stromal matrix compaction and bio assembly would eventually result in an optically clear cornea (11). These have been suggested as possible explanations for the CCT decrease after preterm birth.

Table V. Central corneal thickness in preterm and term newborns

\begin{tabular}{lll}
\hline & $\begin{array}{l}\text { Preterm newborns } \\
\text { CCT }(\mu \mathrm{m}) \\
\text { Mean } \pm \text { SD }\end{array}$ & $\begin{array}{l}\text { Term newborns } \\
\text { CCT }(\mu \mathrm{m}) \\
\text { Mean } \pm \text { SD }\end{array}$ \\
\hline Sehrawat et al (4) & $633.5 \pm 2.8$ & $555.1 \pm 2.7$ \\
Kirwan et al. (2) & $691 \pm 8.7$ & $564 \pm 3.4$ \\
Jethani et al. (7) & $633.5 \pm 2.8$ & $574.4 \pm 78.3$ \\
& & \\
\hline
\end{tabular}

It has been known that monitoring the growth pattern has a great role to predict the future health of a preterm infant. Insufficient postnatal growth catch-up has been reported for term and preterm infants to be associated with poor neurodevelopmental outcomes (12). Early dynamic changes in growth pattern have been particularly based on the measurements of $\mathrm{HC}, \mathrm{BL}$ and $\mathrm{BW}$ in several studies (13-15). In a study, Kıvanç et al. has observed that birth parameters (indicated by GA and BW) have an impact on CCT changes. They indicated that premature children who were small for GA have decreased CCT measurements (16).

In our study, these parameters showed significant increases as the infant gets closer to term. To the best of our knowledge, no study had prospectively evaluated the association between $\mathrm{CCT}$ and growth pattern in preterm neonates. In the present study, we longitudinally investigated changes in CCT and changes in growth reference parameters during 3 months following preterm birth. We observed that decrease in CCT was significantly correlated with increased BL during postnatal 1 st and 2 nd months.
Body length reflects skeletal growth and fat-free mass in growth assessment in preterm infants (17). Skeletal growth depends on interactions of calcium and phosphate minerals where they uniformly bound to the collagen formed matrix. Collagen is the main structural protein in extracellular matrix in various connective tissues such as cornea, bone, cartilage, skin and tendon. It plays an important role in structural maintenance in bone tissue (18). Remodeling of collagen in human fetal cartilage has been shown to result in calcification of human fetal cartilage (19). Same collagen remodeling also occurs in corneal stroma during corneal development in early weeks of life (11). These may partly explain the relationship between CCT and BL changes in the current study. We think that this finding deserves further investigation.

\section{CONGLUSION}

Our study demonstrated significant decrease of CCT along with increase in $\mathrm{HC}, \mathrm{BW}$ and $\mathrm{BL}$ during first 3 months following preterm birth. Decrease of CCT was significantly associated with increase in BL between 1st and 2nd months. Our findings may suggest CCT as a predictor to estimate BL change in preterm infants during early weeks of life. Further studies are required to support results of current study as well as to better ascertain the relationship between CCT and growth reference parameters following preterm birth.

Ethics Committee Approval:This research complies with all the relevant national regulations, institutional policies and is in accordance the tenets of the Helsinki Declaration, and has been approved by the Zeynep Kamil Maternity and Children's Diseases Training and Research Hospital Ethical Committee, (approval number: 19.09.2014/163 ).

Informed Consent: All the participants' rights were protected and written informed consents were obtained before the procedures according to the Helsinki Declaration.

Author Contributions: Concept - G.C. - M.G.; Design G.C - M.G.; Supervision - G.C. - O.K. ; Resources - G.C. O.K.; Materials - G.C. - A.T. - O.K..; Data Collection and/or Processing - G.C - O.K. -A.T. -M.G.; Analysis and/ or Interpretation - A.T. - O.K. ; Literature Search - G.C - M.G.; Writing Manuscript - G.C - M.G.; Critical Review - O.K. A.T.

Conflict of Interest: The authors have no conflict of interest to declare.

Financial Disclosure: The authors declared that this study has received no financial support. 


\section{REFERENGES}

1. Autzen T, Bjørnstrøm L. Central corneal thickness in premature babies. Acta Ophthalmol (Copenh). 1991; 69(2):251-252.

2. Kirwan C, O'Keefe M, Fitzsimon S. Central corneal thickness and corneal diameter in premature infants. Acta Ophthalmol Scand 2005; 83(6):751-753.

3. Uva MG, Reibaldi $\mathrm{M}$, Longo A, et al. Intraocular pressure and central corneal thickness in premature and full-term newborns. J AAPOS 2011; 15(4):367-369.

4. Sehrawat P, Beri S, Garg R, Datta V, Shandil A. Central corneal thickness and corneal diameter in preterm and term newborns and preterm neonates at term. Indian J Ophthalmol 2019; 67(10):1575-1578.

5. Bielemeyer M, Rothschild MA, Schmolling JC, Eifinger F, Banaschak S. Length, weight and head circumference as reliable signs of maturity in a modern German birth collective. Forensic Sci Int 2018; 293:17-23.

6. Rushood AA, Zahrani MH, Khamis A, Rushood AA. Central corneal thickness in full-term Saudi newborns. Acta Ophthalmol 2012; 90(5):e355-e358.

7. Jethani J, Shah K, Jethani M. Evaluating the change in central corneal thickness in neonates (term and preterm) in Indian population and the factors affecting it. Indian journal of ophthalmology 2015; 63(6):501-503.

8. De Silva S, Parentin F, Michieletto P, Pensiero S. Corneal curvature and thickness development in premature infants. J Pediatr Ophthalmol Strabismus 2011; 48(1):25-29.

9. Erginturk Acar D, Acar U, Ozdemir O, Tunay ZO. Determination of normal values of intraocular pressure and central corneal thickness in healthy premature infants-a prospective longitudinal study. J AAPOS 2016; 20(3):239-242.

10. Remón L, Cristóbal JA, Castillo J, Palomar T, Palomar A, Pérez J. Central and peripheral corneal thickness in full-term newborns by ultrasonic pachymetry. Invest Ophthalmol Vis Sci 1992; 33(11):3080-3.

11. Quantock AJ, Young RD. Development of the corneal stroma, and the collagen-proteoglycan associations that help define its structure and function. Dev Dyn 2008; 237(10):2607-2621.

12. Latal-Hajnal B, von Siebenthal K, Kovari H, Bucher HU, Largo RH. Postnatal growth in VLBW infants: significant association with neurodevelopmental outcome. J Pediatr 2003; 143(2):163-170.
13. Giannì ML, Roggero P, Liotto N, Amato O. Postnatal catch-up fat after late preterm birth. Pediatr Res 2012; 72(6):637-640.

14. Roggero $\mathrm{P}$, Giannì ML, Orsi A, et al. Quality of growth in exclusively breast-fed infants in the first six months of life: an Italian study. Pediatr Res 2010; 68(6):542-544.

15. Nash A, Dunn M, Asztalos E, Corey M, Mulvihill-Jory B, O'Connor DL. Pattern of growth of very low birth weight preterm infants, assessed using the WHO Growth Standards, is associated with neurodevelopment. Appl Physiol Nutr Metab 2011; 36(4):562-569.

16. Kıvanç SA, Akova Budak B, Olcaysü OO. Association of Birth Parameters With Corneal Thickness in Prematurely Born and Full-Term School-Aged Children. Cornea 2016; 35(5):634-7.

17. Pereira-da-Silva L, Virella D, Fusch C. Nutritional Assessment in Preterm Infants: A Practical Approach in the NICU. Nutrients 2019; 11(9):1999.

18. Daneault A, Prawitt J, Fabien Soulé V, Coxam V, Wittrant Y. Biological effect of hydrolyzed collagen on bone metabolism. Crit Rev Food Sci Nutr 2017; 57(9):1922-1937.

19. Kirsch $T$, von der Mark K. Remodelling of collagen types I, II and X and calcification of human fetal cartilage. Bone Miner 1992; 18(2):107-117. 